\title{
CONTRIBUTION TO THE CURRENT KNOWLEDGE OF ANT COMMUNITIES (HYMENOPTERA: FORMICIDAE) IN A XEROPHITIC SCRUBLAND OF SOUTHEAST DURANGO, DURANGO
}

\author{
${ }^{1}$ Maria P. Gonzalez-Castillo, ${ }^{2}$ Gerardo Hinojosa Ontiveros and ${ }^{1}$ David Ramírez Noya \\ ${ }^{1}$ Interdisciplinary Research Centre for Integral Regional Development-Durango, \\ National Polytechnique Institute (CIIDIR-IPN-Dgo)., Sigma 119 Fraccionamiento 20 de Noviembre II Durango, \\ Dgo. C.P. 34220, Becaria-COFAA-IPN, México \\ ${ }^{2}$ Instituto Tecnológico del Valle del Guadiana, \\ Carretera Durango-México Km 22.5, Villa Montemorelos Durango, Dgo, México
}

Received 2014-01-07; Revised 2014-02-12; Accepted 2014-02-13

\begin{abstract}
In order to assess the species richness and diversity of ants in a xerophitic scrubland, a total of three areas were monitored in the Southeast of Durango within the municipalities of Nombre de Dios and Durango. Specific richness, relative abundance as well as Shannon's, Simpson's and Pielou's indices of the ant community were obtained. A total of 19 species from 15 genera within four subfamilies were collected: Myrmicinae, Formicinae, Pseudomyrmicinae and Dolichoderinae. The subfamily with the greatest species richness was Myrmicinae (seven species), while Pseudomyrmicinae had the lowest richness with only two species. Dolichoderinae showed the highest relative abundance (76.5\% of the total sample). Four new records of two genera were obtained for the State: Carebara and Linepithema and two species: Atta texana and Myrmecocystus mendax. Shannon's diversity index reached H' $=1.36$, Pielou's evenness index was J' = 0.46 and Simpson's index was $\lambda=0.38$. Further targeted studies are required with different sampling techniques in order to obtain a more detailed listing of ants and increase our knowledge on this group of insects in the study region, which shows high diversity potential.
\end{abstract}

Keywords: Diversity, Abundance, Atta texana, Myrmecocystus mendax

\section{INTRODUCTION}

Insects are the most diverse and evolved group within land arthropods, representing the main functional groups that maintain diversity within ecosystems, with some studies showing their sensitivity to environmental changes caused by anthropogenic activities (Lawton et al., 1998). Research on arthropod biodiversity has been carried out in the valleys of Durango by researchers the CIIDIR-IPN-Dgo. from which a preliminary study on some insect groups within the State was done. Ants were considered within these studied groups, since it is a high-interest group in terms of its biodiversity and due to the functions they carry out within ecosystems. The present work establishes some of the community parameters of this group of insects.

Ants are grouped within the Formicidae family which is placed within the Vespoidea superfamily of the Order Hymenoptera (Rojas, 2001). Currently this family has 21 subfamilies, 307 genera and 12855 species (AntWeb. Available at http://www.antweb.org, Accessed October 29th, 2013). They have a widespread distribution in various biogeographical areas covering a wide variety of habitats worldwide (Hölldobler and Wilson, 1990; $\begin{aligned} \text { Corresponding Author: } & \text { Maria P. Gonzalez-Castillo, Interdisciplinary Research Centre for Integral Regional Development-Durango, } \\ & \text { National Polytechnique Institute (CIIDIR-IPN-Dgo)., Sigma } 119 \text { Fraccionamiento } 20 \text { de Noviembre II Durango, } \\ & \text { Dgo. C.P. 34220, Becaria-COFAA-IPN, México Tel: (52) } 5557296000 \text { ext. } 82646\end{aligned}$ 
Bolton, 1995). They are an important fauna component within arid and semiarid areas due to their high species richness of some taxa having a strong space-time heterogeneity, as well as due to their contribution to the definition of plant community structure and the biological interactions that they establish with other organisms (Polis, 1991; Mackay, 1991; Ríos-Casanova et al., 2004). It has been shown that within these environments there is a surprising level of diversity and abundance of ants and that it is possible to recognize a large variety of trophic interactions and habits that can vary throughout time (Mackay, 1991; Rojas and Fragoso, 2000). Ants reach their highest diversity and abundance within the tropics where there are more species, genera and endemism that in any other region (Bolton, 1995; Fisher et al., 2010). They are the most successful of eusocial insects and have been used as a model for determining fundamental aspects of ecology, evolution, behavior and development (Smith et al., 2009). Studies have been undertaken in some countries using ants as indicators of diversity (Ambrecht and UlloaChacon, 2003) environmental changes and species that efficiently exploit the resources in disturbed ecosystems (Andersen, 1997; Andersen et al., 2002; Andersen and Majer, 2004; Graham et al., 2004; Delabie et al., 2009; Brandao et al., 2012; Achury et al., 2012).

In Mexico, there are 12 formicid subfamilies, with 94 genera and 973 species (Ríos-Casanova, 2013), albeit there are few studies in this country that have been carried out in arid regions. For example, Rico-Gray et al. (2004) evaluated the variation of ant-plant interaction; Rico-Gray (1998) studied the seasonal variation and ant-plant interaction richness in the semiarid Zapotitlan valley; Bestelmeyer and Schooley (1999) studied the dynamics and composition of the ant community in the Sonoran and Chihuahuan desert; Zavala-Hurtado et al. (2000) determined the influence of ant activity on the plant community in Zapotitlan Salinas; Ríos-Casanova et al. (2004) carried out research on ants of the Tehuacan valley; Guzman (2004) carried out work on the foraging pattern of Pogonomyrmex barbatus within two contrasting environments in terms of their diversity and plant cover in the semiarid Zapotitlan Salinas valley, Puebla; Hernández-Ruíz and Castaño-Meneses (2006) studied ant diversity in agricultural ecosystems in the Mezquital valley, Hidalgo; Guzman-Mendoza and Castano-Meneses (2007) studied the foraging activity of Camponotus rubrithorax in the Zapotitlan Salinas valley, Puebla; and finally Varela-Hernández (2013) determined the temporal variation of ant communities in xerophile scrubland with dominance of Cephalocereus senilis and Stenocereus dumortieri in the Meztitlan Biosphere Reserve, Hidalgo. In terms of studies carried out in the northern arid regions of the country, to our knowledge there is only the work carried out by Rojas and Fragoso (2000) in the Mapimi Reserve in the Chihuahuan desert; that of Bestelmeyer and Schooler (1999) and Vasquez-Bolanos (2011) in the southwestern part of the Sonoran desert; the work by AlatorreBracamontes and Vasquez-Bolanos (2010) carried out in various northern States of the country; that of VasquezBolanos (INIFAP, 2011) in which the ant species are listed per State in Mexico; and that of Coronado-Blanco et al. (2013) and Gonzalez et al. (2007) which reports the studies carried out on formicids in the State of Tamaulipas. In light of this, formicids are one of the least known families of the North-Central part of the country.

Species inventories are carried out as a way to gain knowledge on the number of them in a specific habitat, thus the objective of this study was to contribute to the information known on ants within a xerophitic scrubland plant community in Southeast Durango in terms of species richness, abundance and diversity as a basis for future mid- and long-term diversity assessments.

\section{MATERIALS AND METHODS}

Within the framework of the arthropod biodiversity study in the Durango valleys sampling was carried out using entomological nets, yellow traps and manually. The present work reports on biological material obtained from yellow traps and manually.

Study area. The present work was carried out from March 2009 to October 2010 in the municipalities of Nombre de Dios and Durango (Gonzalez-Castillo et al., 2011). A total of three areas representative of xerophitic scrubland were established within these municipalities in the Southeast of Durango State. Information on temperature and annual rainfall was taken from information published by INIFAP (2011). General characteristics of each area are described in Table 1.

Ant sampling. A total of 15 sites were established within each of the three sampling areas. Within each site a $4 \times 4 \mathrm{~m}^{2}$ quadrant was established from which ants observed on plants and on the ground were quantified and collected. A total of 10 quadrants were established, separated from each other by 50 meters. In total $2400 \mathrm{~m}^{2}$ were sampled per area giving a total coverage by this study of $7200 \mathrm{~m}^{2}$.

While yellow traps are not the most recommended method for collecting ants, we obtained good species richness using this method. A trap was placed in each quadrant on the ground using water, to prevent the escape of ants and other specimens, with detergent to break surface tension and 5 gr of sodium borate (borax) for preservation following a modification of the technique proposed by Southwood (1978). Traps were checked and emptied once a week. 
Table 1. Location and brief description of the areas where sampling of ants was carried out in a xerophitic scrubland community in the Southeast of Durango State

\begin{tabular}{|c|c|c|c|c|c|}
\hline Site & $\begin{array}{l}\text { Geographical } \\
\text { coordinates }\end{array}$ & $\begin{array}{l}\text { Average annual } \\
\text { temperature }\left({ }^{\circ} \mathrm{C}\right)\end{array}$ & $\begin{array}{l}\text { Average annual } \\
\text { rainfall } \mathrm{mm} .\end{array}$ & $\begin{array}{l}\text { Elevation } \\
\mathrm{m}\end{array}$ & Plant associations \\
\hline $\begin{array}{l}\text { Tuitán (T), } \\
\text { Nombre de Dios }\end{array}$ & $\begin{array}{l}\text { Lat. N } 24^{\circ} 02^{\prime} 32^{\prime \prime} \\
\text { Long. W } 104^{\circ} 14^{\prime} 01^{\prime \prime}\end{array}$ & 16.6 & 452 & 1886 & $\begin{array}{l}\text { Opuntia sp., Acacia sp., Dasylirium sp., } \\
\text { (Gonzalez-municipality, Dgo Castillo et al., } \\
\text { 2011), Yucca sp., Mimosa biuncifera } \\
\text { (Benth) Bouteloua gracilis (Will.ex Kunth). }\end{array}$ \\
\hline $\begin{array}{l}\text { Nombre de Dios } \\
\text { (ND), Nombre de } \\
\text { Dios municipality, Dgo. }\end{array}$ & $\begin{array}{l}\text { Lat. N } 23^{\circ} 49^{\prime} 26^{\prime \prime} \\
\text { Long. W } 104^{\circ} 13^{\prime} 28^{\prime \prime}\end{array}$ & 16.9 & 367 & 1809 & $\begin{array}{l}\text { Prosopis sp., Acacia sp., } \\
\text { Opuntia } \mathrm{sp} . \text { Agave } \\
\text { durangensis Gentry }\end{array}$ \\
\hline $\begin{array}{l}\text { Sierra El Registro } \\
\text { (SR), Durango } \\
\text { municipality, Dgo. }\end{array}$ & $\begin{array}{l}\text { Lat. N } 23^{\circ} 37^{\prime} 47^{\prime \prime} \\
\text { Long. W } 104^{\circ} 22.5^{\prime} 13^{\prime \prime}\end{array}$ & 16 & 400 & 1928 & $\begin{array}{l}\text { Agave durangensis Gentry, Prosopis } \\
\text { laevigata (Hum. Et Bonpl. Ex Willd), } \\
\text { Acacia schaffneri (S. Watson), Dasyliriom } \\
\text { duranguense (Trel), Bouteloua gracilis } \\
\text { Willd. Ex Kunt) Lag. (Gonzalez et al., 2007). }\end{array}$ \\
\hline
\end{tabular}

Sampling of ants was complemented by manually picking them as they were observed in dead leaves and under rocks and rotten tree trunks using paintbrushes dipped in $70 \%$ alcohol as well as entomological tweezers.

Biological material was taken to the Entomology Laboratory of the CIIDIR-IPN, U. Dgo., for their separation and quantification.

Approximately 10 individuals from each species were mounted using entomological pins while the remainder of the material was placed in jars with $70 \%$ ethanol. Ants were classified taxonomically to the genus level (some to species level) using Mackay and Mackay (1989) and Bolton (1994) taxonomic keys as well as the help of an expert from the Faculty of Sciences of the National Autonomous University of Mexico (UNAM). All specimens were deposited in the Entomological Collection of CIIDIRIPN, U. Dgo. Analysis of diversity. Specific species richness was assessed (number of species) while Moreno (2001) index was used to calculate the average richness. Absolute abundance $(\mathrm{N})$ of species, species morphs, genera and subfamilies was determined for the entire study area, as well as the relative abundance (\%). Relative abundance was obtained using the frequency of occurrence of species in each area (Sanchez and Antonio, 2004). A total of 15 sites per area were obtained totaling 45 sites in the study.

Diversity in the study area was estimated using Shannon's (H') index which is a maximum likelihood estimator and is the most sensitive to changes in abundance of rare families (Magurran, 1989; Gonzalez-Castillo et al., 2011), the index ranges between 1.5 and 3.5 representing the uncertainty there is when collecting an individual of a species in terms of the species to which the next individual will belong to. Pielou's evenness $(\mathrm{J})$ index, which expresses evenness as the proportion of the observed diversity in regards to the maximum expected diversity, was also estimated (Moreno, 2001; Magurran, 1989; Gonzalez-Castillo et al., 2011). Furthermore,
Simpson's $(\lambda)$ index, which manifests the probability that two individuals randomly chosen from a sample are from the same species and that is influenced by the most abundant species in the sample, was also calculated (Moreno, 2001; Magurran, 1989).

\section{RESULTS}

Richness, composition and abundance. Taking into consideration the entire study area, a total of 19,480 ants were collected belonging to 15 species morphs and four species within 15 genera of four subfamilies. Myrmicinae, Formicinae, Pseudomyrmicinae and Dolichoderinae (Table 2). The subfamily with the highest species richness was Myrmicinae (seven species) while that which had the least richness was Pseudomyrmicinae with only two species. Figure 1 shows that Dolichoderinae had the highest relative abundance $(76.5 \%)$ while Pseudomyrmicinae had the lowest relative abundance $(<1 \%)$.

The specific richness of the study area reached 19 .

Of the 15 genera found, Forelius had the greatest species richness (3), while Camponotus and Pseudomyrmex had two species each and the remaining genera had only one species or species morph each.

The relative abundance was obtained from the species frequency per area; as such in the study area it was Pheidole sp. which showed the highest relative abundance, followed by Myrmecocystus mendax Wheeler, Monomorium sp., Liometopum sp., Camponotus sp. and Brachymyrmex depilis Emery, with the remaining species and species morphs representing less than 5\% (Fig. 2).

Species diversity. Globally from the study area Shannon's diversity index reached $H^{\prime}=1.3$. Pielou's evenness index reached J' $=0.46$ and Simpson's index was $\lambda=0.38$. 


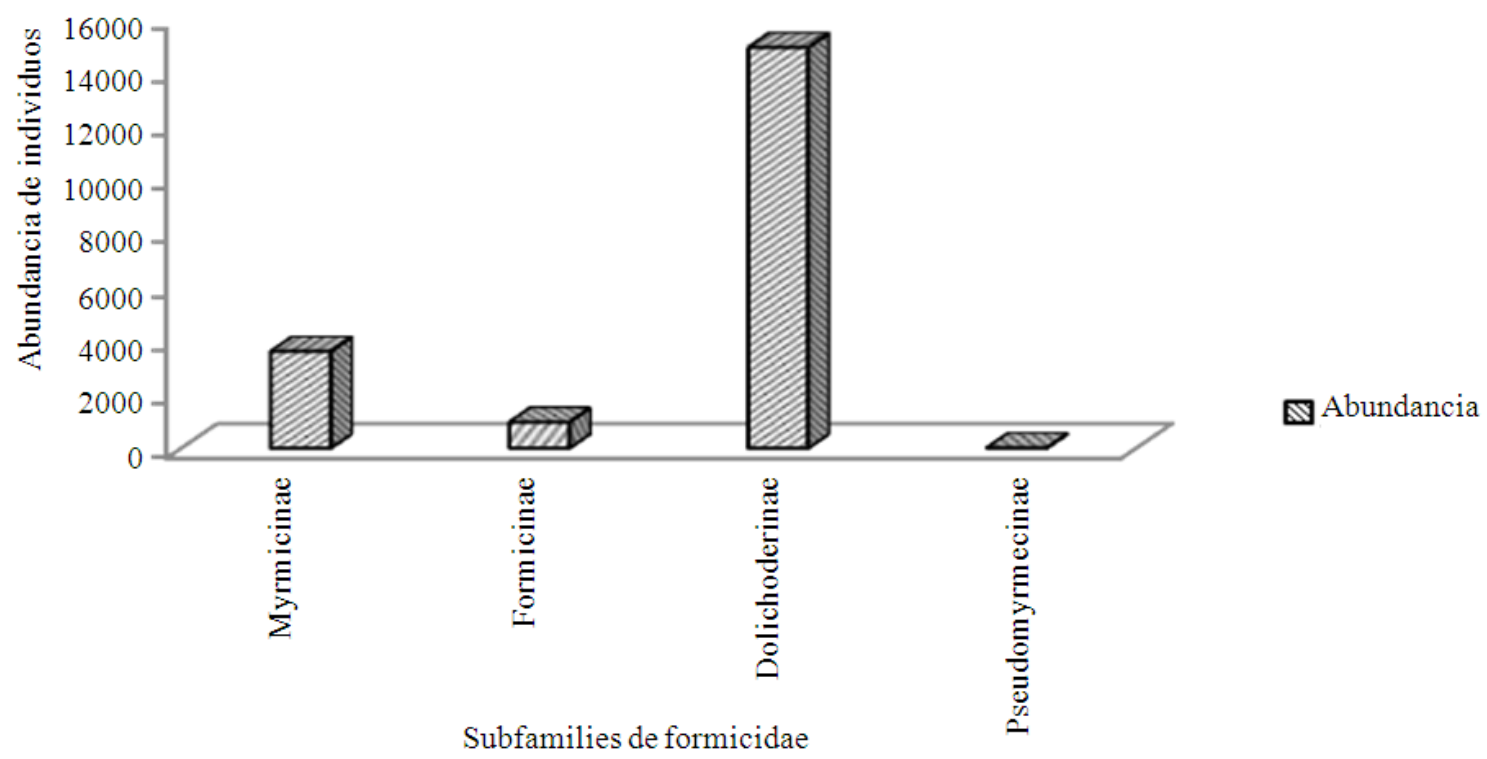

Fig. 1. Abundance of the ant subfamilies represented in the xerophitic scrubland

Table 2. Total genera, species and species morphs of ants collected from xerophitic scrubland in the Southeast of Durango State. The genera and species names in bold are new records for the State

\begin{tabular}{|c|c|c|}
\hline $\begin{array}{l}\text { Subfamilies } \\
\text { /Tribes }\end{array}$ & $\begin{array}{l}\text { Genera/Species } \\
\text { /Species } \\
\text { specimens }\end{array}$ & $\begin{array}{l}\text { Total } \\
\text { Morphs }\end{array}$ \\
\hline \multicolumn{3}{|l|}{ Dolichoderinae } \\
\hline Dolichoderini & $\begin{array}{l}\text { Dorymermex sp. } \\
\text { Forelius sp. I } \\
\text { Forelius sp. II } \\
\text { Forelius sp. III } \\
\text { Linepithema sp. } \\
\text { Liometopum sp. }\end{array}$ & $\begin{array}{r}2585 \\
1046 \\
9 \\
8 \\
22 \\
11234\end{array}$ \\
\hline \multicolumn{3}{|l|}{ Formicinae } \\
\hline Camponotini & $\begin{array}{l}\text { Camponotus sp. I } \\
\text { Camponotus sp.II }\end{array}$ & $\begin{array}{r}116 \\
1\end{array}$ \\
\hline Lasini & $\begin{array}{l}\text { Myrmecocystus } \\
\text { mendax Wheller }\end{array}$ & 688 \\
\hline Plagiolepidini & $\begin{array}{l}\text { Brachymyrmex } \\
\text { depilis Emery }\end{array}$ & 162 \\
\hline $\begin{array}{l}\text { Pseudomyrmecinae } \\
\text { seudomyrmecini }\end{array}$ & $\begin{array}{l}\text { Pseudomyrmex } \\
\text { pallidus (Smith) }\end{array}$ & 11 \\
\hline Myrmicinae & Pseudomyrmex sp. & 1 \\
\hline Attini & Atta texana Buckley & 4 \\
\hline Crematogastrini & Crematogaster sp. & 41 \\
\hline Myrmecinici & Pogonomyrmex sp. & 1 \\
\hline Pheidolini & $\begin{array}{l}\text { Aphaenogaster sp. } \\
\text { Pheidole sp. }\end{array}$ & $\begin{array}{r}1 \\
2909\end{array}$ \\
\hline Solenopsidini & $\begin{array}{l}\text { Carebara sp. } \\
\text { Monomorium sp. }\end{array}$ & $\begin{array}{r}6 \\
635\end{array}$ \\
\hline Total & & 19480 \\
\hline
\end{tabular}

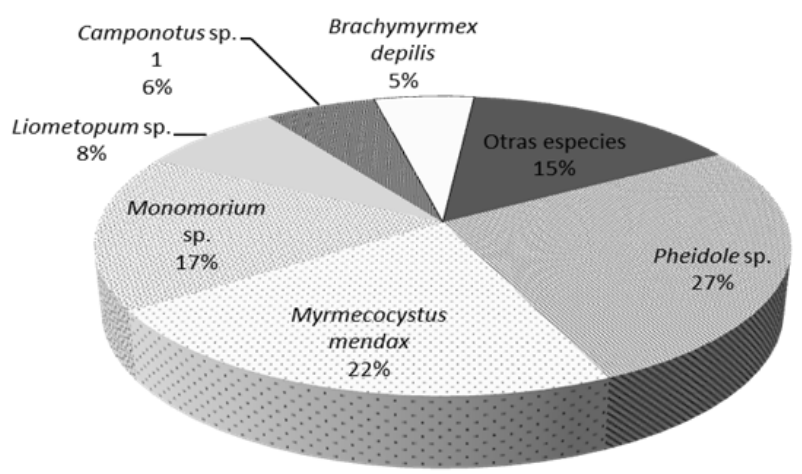

Fig. 2. Relative abundance of ant species and species morphs in the xerophitic scrubland under study other species

\section{DISCUSSION}

Richness, composition and abundance. It is noteworthy that in a $7200 \mathrm{~m}^{2}$ area two species in two genera were found to be new records for the State directly contributing to the local diversity partly due to the heterogeneity of xerophile scrubland since there is a great diversity of plant species in the studied area creating specific favorable conditions to accommodate various ant species.

The Myrmicinae subfamily showed the highest genera and species richness in agreement with other studies carried out in arid or semiarid areas at the state, national (Rojas, 2001; Ríos-Casanova, 2013) and worldwide (Wilson, 2003) levels, where it is seen as the 
most numerous. It is also considered to be an indicator of disturbed environments (Fernandez, 2003). This subfamily was followed in order of importance by Dolichoderinae, Mirmicinae and Pseudomyrmicinae, the latter with the least number of species.

In regards to the relative abundance per subfamily, Dolichoderinae showed the highest level at $76.5 \%$ followed by Myrmicinae with $18.5 \%$ and Formicinae with 5\%, while Pseudomyrmicinae represented less than $0.1 \%$. The abundance of Dolichoderinae was due to the fact that Liometopum sp accounted for many of the ants collected, but these were not found within all sites. This species morph was located within brush, grassland and mainly on Agave durangensis Gentry, possibly preferring agave because of the sugary secretions of the agave scale Acutaspis agavis Townsend and Cockerell. Furthermore, the fact that Liometopum sp is dominant within an ecosystem provides insight into the level of disturbance or alterations that various areas have. According to several studies, such as that of Andersen et al. (2002) they are considered as indicators of disturbance and therefore they could be used as sentinels in environmental impact studies. Notwithstanding, the high dominance of this species morph could also be due to a lower predator density (Rao et al., 2001).

Regarding the relative abundance by species and species morphs, Fig. 2 clearly shows that Pheidole sp. Myrmecocystus mendax Wheeler and Monomorim sp. constitute $66 \%$ of the species. Furthermore, Brachymyrmex depilis Emery, Camponotus sp. and Liometopum sp. 1 constitute between 5 and $8 \%$, while Forelius sp., Linepithema sp., Crematogaster sp., Camponotus sp. 2, Pseudomyrmex sp. 2, Pseudomyrmex pallidus (Smith) Forelius sp. 2, Dorymermex sp., Carebara sp., Aphaenogaster sp., Forelius sp. 3 and Atta texana Buckley represented less than $5 \%$ of the relative abundance. It must be noted that Pheidole sp also prefers agave due to the sugary secretions of the agave scale $A$. agavis. As stated in other studies, M. mendax is one of the most important omnivorous species of arid areas since they consume a large amount of insect cadavers and plant and animal sugary exudates and have the special adaptation to extreme conditions in which they store sweet fluids within the body of specific individuals in their colonies for their use in times of shortage (Rojas, 2001). This ant can be found in at least six States in the Mexican Republic (Vasquez-Bolanos, 2011).

In contrast, Dorymyrmex $\mathrm{sp}$ is one of the species with the least relative abundance. This genus is exclusively found in America with more than 80 described species, 50 of which are found in the neotropical zone.
Furthermore, species in this genus have been described to construct their nests on the ground of arid and semiarid regions preferring open spaces with little plant cover where they are dominant from an ecological point of view. They encompass the entire continent, from the United States of America to Argentina (Cuezzo, 2003). In Mexico, six species of this genus have been collected in 11 States, with one species found in Durango (Vasquez-Bolanos, 2011).

Forelius sp. 1 are known to always nest in soil of desert or semi-desert environments with little plant cover and has two distinct apparently disjointed distribution areas, one in central and southern United States, northern Mexico, Cuba, Honduras and islands in Central America, while the other is located in South America, Bolivia, Brazil, Uruguay, Paraguay, Chile and Argentina (Calle et al., 2013).

Furthermore, B. depilis was found to be associated to mesquite which is in agreement with studies by Fernandez (2003) where he mentions that they are frequently associated with leguminous plants. This ant species has been previously collected in six States in Mexico, including Durango (Vasquez-Bolanos, 2011). Pseudomyrmex pallida (Smith) is widely distributed throughout Mexico with records encompassing 21 States (Vasquez-Bolanos, 2011). Finally, for Aphaenogaster sp. two species have been recorded for Durango (Vasquez-Bolanos, 2011), although several species of this genus have been observed more frequently in areas with tropical climate (Escalante et al., 2004).

The fact that four dominant species were found within the three sites and that 11 species/species morphs were exclusive suggests that within xerophitic scrubland there are microclimates, microhabitats and resources for species with contrasting habits, with some predominating on the ground and others on the vegetation feeding on the sugary secretions of pseudococcids of certain plants and on larvae of insects and other arthropods (Longino and Hanson, 1996).

Shannon's diversity index was low at $\mathrm{H}^{\prime}=1.3$ and Majer (1983) states that Shannon's index levels below 1.5 are frequently associated with altered environments.

New ant records for the State. It is noteworthy that for the first time two new genera and two new species were recorded in the State which are Carebara and Linepithema and the species Myrmecocystus mendax Wheeler and Atta texana Buckley. Carebara was scantily observed and only one species has been found in two Mexican States (Vasquez-Bolanos, 2011). Also, three species of the Linepithema genus have been recorded in three States in the country (Vasquez-Bolanos, 2011). The majority of the species in this genus build their nests on the ground, fallen 
leaves or under rocks and have been observed in grasslands and disturbed habitats (Will, 2007).

Atta texana was also scantily observed $(<1 \%)$ and is considered to be a leaf cutter and fungus cultivator (Hölldobler and Wilson, 1990). It has been collected in clearings with pecan (Carya illinoinensis (Wangenh) $\mathrm{K}$. Koch) and sweet acacia (Acacia farnesiana (L.) Willd) (Sánchez-Peña, 2010), in six States of the Mexican Republic (Vasquez-Bolanos, 2011; Escoto et al., 2001). This species is known as "chicatana" and is eaten by people in Cordoba, Papantla and Teocelo in Veracruz (Landero-Torres et al., 2004).

Vasquez-Bolanos (2011) listed a total of 884 ant species for Mexico, of which 58 were found in Durango, although Ríos-Casanova (2013) mentioned that there were in fact 60 species. In this study we found 19 species, or less than $50 \%$ of what has been reported previously, albeit of these 19 species four are new records for the State increasing the total species expected to be in the State to 64 .

Variation can be seen in terms of species found, when comparing the present study with other previously published from similar areas, mainly due to the differences in habitats sampled, sampling methods, length of sampling, repetitiveness of the sampling and emphasis of sampling of ants in the different studies. Delabie and Blard (2002) state that the use of different sampling methods increases the probability of finding new species in each study area. The amount of species found in this study area places it as a highly important one for the biological conservation of xerophitic scrubland.

\section{CONCLUSION}

Even though sampling in this study was not specific for ants and the traps used were not ideal for them it was possible to find four new records for the State. Nevertheless, greater efforts must be placed on sampling using other methods (fall traps, baits, pitfall and others) that are complementary and optimal for the different types of vegetation in the State, which would allow a more detailed listing to be obtained increasing the current knowledge on this group of insects in the study region that already shows high diversity potential. It would also allow the establishment of the relationship there is between ants, vegetation types and environmental parameters. Detailed species determination is needed for all ants collected since only $21 \%$ of them achieved such level of classification.

Predominance of the Myrmicinae family suggests that the study area suffers from a certain degree of disturbance. It was possible to observe that there is a transformation of the natural environment into agricultural landscapes, grasslands and human habitation, which are factors that modify the structure of ant communities and in turn making species composition different between study sites. This agrees with several authors that have stated that ants are an indicator of specific environmental conditions in regards to their environmental preferences and tolerance to conspicuous factors such as temperature and habitat selection (Majer, 1983; Power, 1996).

\section{ACKOWLEDGEMENT}

Researchers wish to thank SIP-IPN (GonzalezCastillo et al., 2011) for the funding of projects 20113567 and 20120473, as well as to Dr. Gabriela Castaño-Meneses of the Multidisciplinary Teaching and Research Unit of the Science Faculty, UNAM for revising the manuscript.

\section{REFERENCES}

Achury, R., P.C.D. Ulloa and A. Arcilla, 2012. Effects of the Heterogeneity of the landscape and the Abundance of Wasmannia auropunctata on Ground Assemblages ina Colombian tropical Dry Forest. Psyche, 2012: 960475-960486. DOI: 10.1155/2012/960475

Alatorre-Bracamontes, C.E. and M. Vasquez-Bolanos, 2010. Lista comentada de las hormigas (Hymenoptera: Formicidae) del norte de México. Dugesiana, 17: 9-36.

Ambrecht, I.Y. and P. Ulloa-Chacon, 2003. The little fire ant wasmannia auropunctata (Roger) (Hymenoptera: Formicidae) as a diversity indicator of ants in tropical dry forest fragments of Colombia. Environ. Entomol., 32: 542-547. DOI: 10.1603/0046-225X-32.3.542

Andersen, A.N. and J.D. Majer, 2004. Ants show the way down under: Invertebrates as bioindicators in land management. Front. Ecol. Environ., 2: 291-298. DOI: $10.1890 / 1540-$ 9295(2004)002[0292:ASTWDU]2.0.CO;2

Andersen, A.N., 1997. A conservation outside nature reserves. Universidad de Queen.

Andersen, A.N., D.B. Hoffmann, W.J. Mueller, Y.A.D. Griffiths, 2002. Using ants as bioindicators in land management: Simplifying assessment of ant community responses. J. Applied Ecol., 39: 8-17. DOI: $10.1046 /$ j.1365-2664.2002.00704.x

Bestelmeyer, B.T. and R.L. Schooley, 1999. The ants of the Southern Sonoran desert: Community, structure and the role of trees. Biodivers. Conser., 8: 643-657. DOI: 10.1023/A:1008873406658

Bolton, B., 1994. Identification guide to the Ant Genera of the World. 1st Edn., Harvard University Press, Cambridge, Massachusetts, ISBN-10: 0674442806, pp: 232. 
Bolton, B., 1995. A taxonomic and zoogeographical census of the extant ant taxa (Hymenoptera: Formicidae). J. Natural History, 29: 1037-1056. DOI: 10.1080/00222939500770411

Brandao, C. R.F., Rogerio R. Silva and Jacques H.C. Delabie, 2012. Neotropical ants (Hymenoptera) Functional Groups: Nutritional and Applied Implications. In: Insect Bioecology and Nutrition for Integrated Pest Management, Panizzi, A.R. and J.R.P. Parra (Eds.), CRC Press, ISBN-10: 1439837082, pp: 213-236.

Calle, Z. N. Henao-Gallego, C. Giraldo and I. Armbrecht. 2013. A Comparison of vegetation and grounddwelling ants in abandoned and restored gullies and landslide surfaces in the western colombian andes. Restorat. Ecol., 21: 729-735. DOI: 10.1111/rec.12001

Coronado-Blanco, J.M., D.A. Dubovikoff, E.R. Cancino, M. Vasquez-Bolanos and K.Y.F. Maldonado, 2013. Formicidae (Hymenoptera) del estado de tamaulipas, México. Cienciauat, 25: 12-17.

Cuezzo, F., 2003. Subfamilia Dolichoderinae. In: Introducción a Las Hormigas de la Región Neotropical, Fernandez, F. (Ed.), Instituto de Investigación de Recursos Biol. Alexander von Humboldt. Bogotá, Colombia, pp: 291-298.

Delabie, H.C.J. and F. Blard, 2002. The tramp ant Hypoponera punctatissima (Roger) (Hymenoptera: Formicidae: Ponerinae): New records from the Southern Hemisphere. Neotropical. Entomol., 31: 149-151.

Delabie, H.C.J., R. Céréghino, S. Groc, A. Dejea and M. Gibernau, 2009. Ants as biological indicators of wayana amerindian land use in French Guiana. C.R. Biol., 332: 673-684. PMID: 19523607

Escalante, J.A.L., S.J. Ponce, M.C.A. Tena, T.Y.R.C. Chavarria and M.A. Morales, 2004. Primer inventario de hormigas (Hymenoptera: Formicidae) del estado de Michoacán, México. En: Entomología Mexicana. Colegio de Postgraduados, Montecillo, Texcoco, Estado de México.

Escoto, R.J., G.H.J. Cruz and S.L. Delgado, 2001. Biodiversidad de hymenoptera del estado de aguascalientes, México. Invest. Ciencia, 24: 20-27.

Fernandez, F., 2003. Introducción a las Hormigas de la Región Neotropical. 1st Edn., Instituto de Investigación de Recursos Biológicos Alexander Von Humboldt, Bogotá, Colombia, pp: 398.

Fisher, B.L., L.C.L. Parr and K.L. Abbott, 2010. Biogeography. 1st Edn., Oxford University Press, New York.
Gonzalez, E.S., E.M. Gonzalez and L.Y. M.A. Márquez, 2007. Vegetación y Ecorregiones de Durango. 1st Edn., Plaza y Valdés, ISBN-10: 9707226986, pp: 219.

Gonzalez-Castillo, M.P., M. Quinhtos E. and G. CastañoMeneses, 2011. Arthropods in natural communities in mescal agave (agave durangensis gentry) in an arid zone. Am. J. Applied Sci., 8: 933-944. DOI: 10.3844/ajassp.2011.933.944

Graham, H.J., H.H. Hughie, S. Jones, K. Wrinn and A. J. Krzysik, 2004. Habitat disturbance and the diversity and abundance of ants (Formicidae) in the Southeaster fall-line Sandhills. J. Insect Sci.

Guzman, M.R., 2004. Patrones de actividad de forrajeo de Pogonomyrmex barbatus en el Valle semiárido intertropical de zapotitlán salinas, puebla. Tesis de Maestría. Universidad autónoma metropolitana. México. D.F., pp: 108.

Guzman-Mendoza, R. and G. Castano-Meneses, 2007. Selected foraging activity of camponotus rubrithorax (Hymenoptera: Formicidae) in the zapotitlán salinas valley, Puebla, Mexico. Sociobiology, 50: 435-448.

Hernández-Ruíz, P. and G. Castaño-Meneses, 2006. Ants (Hymenoptera: Formicidae) diversity in agricultural ecosystems at Mezquital valle, Hidalgo, Mexico. Eur. J. Soil Biol., 42: 208-212. DOI: 10.1016/j.ejsobi.2006.07.020

Hölldobler, B. and E.O. Wilson, 1990. The Ants. 1st Edn., Harvard University Press, Cambridge, Massachusett, pp: 732.

INIFAP, 2011. Red nacional de estaciones Agroclimatológicas.

Landero-Torres, I., M.A. Morales, G.M. Ibarra, G.A.P Rivera and S.C. Stanford, 2004. Las Chicatanas Atta sp. Un Recurso Natural Aprovechado en Diversas Localidades del Estado de Veracruz. Entomol. Mexicana Colegio de Postgraduados, Montecillo, Texcoco, Estado de México.

Lawton, J.H., D.E. Bignell, B. Bolton, G.F. Bloemers and P. Eggleton, 1998. Biodiversity inventories, indicator taxa and effects of habitat modifications in tropical forest. Nature, 391: 72-76. DOI: $10.1038 / 34166$

Longino, J.T. and P.E. Hanson, 1996. The Ant (Formicidae). In: The Hymenoptera Costa Rica, Hanson, P.E. and I.D. Gauld (Eds.), Oxford University Press, Oxford, ISBN-10: 0198549059.

Mackay, W.P., 1991. The Role of Ants and Termites in Desert Communities. In: The Ecology of desert communities, Polis, G.A. (Ed.). University of Arizona Press. Tucson, ISBN-10: 0816511861, pp: 113-150. 
Mackay, W.P.Y. and E. Mackay, 1989. Clave para los géneros de hormigas en México (Hymenoptera: Formicidae), El Paso, Tx., EUA.

Magurran, A., 1989. Diversidad ecológica y su medición. ediciones vedrá. Barcelona españa.

Majer, J.D., 1983. Ants: Bio-indicators of minesite rehabilitation, land-use and land conservation. Environ. Manage., 7: 375-384. DOI: 10.1007/BF01866920

Moreno, C.E., 2001. Métodos Para Medir la Biodiversidad. 1st Edn., Sociedad Entomológica Aragonesa, Zaragoza, ISBN-10: 8492249528, pp: 83.

Polis, G.A., 1991. The Ecology of Desert Communities. 1st Edn., University Arizona Press, Tucson, ISBN10: 0816511861, pp: 456.

Power, A., 1996. Arthropod Diversity in Forest Patches and Agroecosystems of Tropical Landscapes. In: Forest Patches in Tropical Landscapes, Schelhas, J. and R. Greenberg (Eds.), Island Press, Washington, ISBN-10: 1610912691.

Rao, M., J. Terborgh and Y.P. Nuñez, 2001. Increased herbivory in forest isolates: Implications for plant community structure and composition. Conserv. Biol., 15: 624-633. DOI: 10.1046/j.15231739.2001.015003624.x

Rico-Gray, V., M.P. Ríos, J.G.G. Franco and W.P. Mackay, 1998. Richness and seasonal variation of ant-plant association mediated by plant derived food resources in the semiarid zapotitlan valley, Mexico. Am. Mid. Nat., 140: 21-26. DOI: 10.1674/00030031(1998)140[0021:RASVOA]2.0.CO;2

Rico-Gray, V., P.S. Oliveira, V. Parra-Tabla, M. Cuautle and C. Díaz-Castelazo, 2004. Ant-Plant Interactions: Their Seasonal Variation and Effects on Plant Fitness. In: Coastal Dunes: Ecology and Conservation Martínez, M.L. and N.P. Psuty (Eds.), Springer, Berlin, ISBN-10: 3540408290, pp: 221-239.

Ríos-Casanova, L., 2013. Biodiversidad de hormigas en México. Revista Mexicana de Biodiversidad.

Ríos-Casanova, L., A.V. Banuet and Y.V.R. Gray, 2004. Las hormigas del Valle de tehuacán, (Hymenoptera: Formicidae): Una comparación con otras zonas áridas de México. Acta Zool. Mexicana, 20: 37-54.

Rojas, F.P., 2001. Las hormigas del suelo en México: Diversidad, distribución e importancia hymenoptera: Formicidae. Acta zoológica mexicana (n.s). Número Especial, 1: 189-238.
Rojas, P. and C. Fragos, 2000. Composition, diversity and distribution of a Chihuahuan desert ant community (Mapimi, México). J. Arid Environ., 44: 213-227. DOI: 10.1006/jare.1999.0583

Sanchez, C. and A. Antonio, 2004. Diversity, abundance, seasonality and interactions of ants (Hymenoptera: Formicidae) in pecans in Mumford, Robertson Co., Texas. Master's thesis, Texas A\&M University. Texas A\&M University. Available electronically.

Sánchez-Peña, S., 2010. Some fungus-growing ants (Hymenoptera: Formicidae) from Northeastern Mexico. Florida Entomol., 93: 501-504. DOI: 10.1653/024.093.0404

Smith, R.C., A. Dolezal, D. Eliyahu, C. T. Holbrook and J. Gadau, 2009. Ant (formicidae): Models for social complexity. Cold spring harb protoc, última consulta 4-noviembre-2013.

Southwood, T.R.E., 1978. Ecological Methods. 1st Edn., Capman Hall, London New York, pp: 524.

Varela-Hernández, F., 2013. Variación temporal de las comunidades de hormigas en matorral xerófilo con dominancia de Cephalocereus senilis y Stenocereus dumortieri en la reserva de la biosfera barranca de metztitlán, Hidalgo, México. Rev. Peru. Entomol.

Vasquez-Bolanos, V.M., 2011. Lista de especies de hormigas (Hymenoptera: Formicidae) para México. Dugesiana, 18: 95-133.

Will, A.L., 2007. Taxonomic revision of the ant genus Linepithema (Hymenoptera: Formicidae). Univ. California Public. Entomol., 126: 1-151.

Wilson, E.O., 2003. La Hiperdiversidad Como Fenómeno Real: El caso de Pheidole. In: Hormigas De La Región Neotropical, Fernandez E. (Ed.), Instituto de investigación de recursos Biológicos Alexander von Humboldt, Bogotá, Colombia, pp: 363-370.

Zavala-Hurtado, J.A., P.L. Valverde, M.C.H. Fuentes and A.D. Solís, 2000. Influence of leaf-cutting ants (Atta mexicana) on performance and dispersion patterns of perennial desert shrubs in a Inter.tropical region of central mexico. J. Arid Environ., 46: 93-102. DOI: 10.1006/jare.2000.0655 